\title{
Linear relationship between increasing amounts of extruded linseed in dairy cow diet and milk fatty acid composition and butter properties
}

\author{
C. Hurtaud, ${ }^{*} \dagger^{1}$ F. Faucon, $\ddagger$ S. Couvreur, $\S$ and J.-L. Peyraud ${ }^{*} \dagger$ \\ *INRA UMR1080 Production du Lait, F-35590 Saint-Gilles, France \\ †Agrocampus Ouest UMR1080 Production du Lait, F-35000 Rennes, France \\ †Institut de l'Elevage, F-75012 Paris, France \\ §Groupe ESA, Equipe Enseignement et Recherche en Zootechnie, 55 rue Rabelais, BP30748, F-49007 Angers Cedex 1, France
}

\section{ABSTRACT}

The aim of this experiment was to compare the effects of increasing amounts of extruded linseed in dairy cow diet on milk fat yield, milk fatty acid (FA) composition, milk fat globule size, and butter properties. Thirty-six Prim'Holstein cows at $104 \mathrm{~d}$ in milk were sorted into 3 groups by milk production and milk fat globule size. Three diets were assigned: a total mixed ration (control) consisting of corn silage (70\%) and concentrate (30\%), or a supplemented ration based on the control ration but where part of the concentrate energy was replaced on a dry matter basis by $2.1 \%$ (LIN1) or $4.3 \%$ (LIN2) extruded linseed. The increased amounts of extruded linseed linearly decreased milk fat content and milk fat globule size and linearly increased the percentage of milk unsaturated FA, specifically $\alpha$-linolenic acid and trans FA. Extruded linseed had no significant effect on butter color or on the sensory properties of butters, with only butter texture in the mouth improved. The LIN2 treatment induced a net improvement of milk nutritional properties but also created problems with transforming the cream into butter. The butters obtained were highly spreadable and melt-in-the-mouth, with no pronounced deficiency in taste. The LIN1 treatment appeared to offer a good tradeoff of improved milk FA profile and little effect on butter-making while still offering butters with improved functional properties.

Key words: dairy cow, extruded linseed, milk fatty acid, butter

\section{INTRODUCTION}

One of the objectives of the milk industry is to improve the nutritional quality of milk fat by reducing saturated fatty acids (FA), particularly the atherogenic palmitic acid (Nicolis, 1997), in favor of polyunsaturated

Received October 20, 2009.

Accepted December 21, 2009

${ }^{1}$ Corresponding author: Catherine.Hurtaud@rennes.inra.fr
FA. The aim is to increase the content of n-3 series FA, including $\alpha$-linolenic acid (ALA), which is recognized as minimizing the risk of cardiovascular disease and is equally essential for the functional development of the central nervous system (myelin; ANC, 2001), and conjugated linoleic acid (CLA), including rumenic acid, which appears to show anticarcinogenic properties (Williams, 2000).

It is now well established that supplementation of cow diet with unsaturated FA affects milk FA profiles (Chilliard et al., 2000; Harvatine et al., 2009). Adding encapsulated-form rapeseed, sunflower, soybean, or cottonseed oil produces milk with 15 to $20 \%$ linoleic acid content, whereas the effect is more moderate in diets rich in nonprotected seeds ( $4 \%$ linoleic acid). Linseed is particularly rich in ALA and induces an increase in milk ALA content whatever the feed form: whole seed (Kelly et al., 1998; Ward et al., 2002), ground seed (Collomb et al., 2004), extruded seed (Schori et al., 2006), or oil (Offer et al., 1999; Dhiman et al., 2000). Collomb et al. (2004) found that the percentage of ALA in milk doubled after feeding ground linseed compared with a hay and beet-based control diet. Their study did not find a seed effect on milk fat content, whereas diets supplemented with various lipid sources are often reported to decrease milk fat content (Chilliard and Ferlay, 2004).

The decreases in milk fat yield with linseed supplementation appear to be fairly random, relatively uncontrollable, and occasionally dramatic. For these linseed-based supplements to be used rationally on farm, it would be useful to plot the dose-response effects of increasing dietary quantities of extruded linseed on the zootechnical results of dairy cows and the milk FA profiles. Little research has been done regarding the effect of linseed on the sensory quality of milk products; therefore, we have studied the effect of increasing doses of extruded linseed on the taste-texture properties of butter. Butter was chosen among dairy products because it gives the best indication of changes occurring in milk FA profile. 
Table 1. Chemical composition and nutritional value of feeds

\begin{tabular}{|c|c|c|c|c|c|}
\hline $\begin{array}{l}\text { Item, } \mathrm{g} / \mathrm{kg} \text { of } \mathrm{DM} \\
\text { unless noted }\end{array}$ & $\begin{array}{l}\text { Corn } \\
\text { silage }\end{array}$ & $\begin{array}{c}\text { Energy } \\
\text { concentrate }^{1}\end{array}$ & $\begin{array}{c}\text { Soybean } \\
\text { meal } 48\end{array}$ & $\begin{array}{l}\text { Valomega } \\
160^{2}\end{array}$ & $\begin{array}{c}\text { Minerals } \\
6-24-4^{3}\end{array}$ \\
\hline DM, \% & 33 & 85 & 87.8 & 89.8 & 100 \\
\hline $\mathrm{NE}_{\mathrm{L}}$, Mcal $/ \mathrm{kg}$ of DM & 1.56 & 1.80 & 2.00 & 2.69 & - \\
\hline $\mathrm{N}$ & 73 & 119 & 488 & 215 & - \\
\hline $\mathrm{OM}, \mathrm{g} / \mathrm{kg}$ & 962 & 951 & 931 & 958 & - \\
\hline NDF & 392 & 261 & 143 & 335 & - \\
\hline $\mathrm{ADF}$ & 201 & 91 & 79 & 146 & - \\
\hline Starch & 302 & 470 & 62 & 126 & - \\
\hline $\mathrm{PDIE}^{4}$ & 65 & 98 & 219 & 147 & - \\
\hline $\mathrm{PDIN}^{5}$ & 45 & 80 & 338 & 168 & - \\
\hline $\mathrm{Ca}$ & 1.7 & 4.0 & 3.9 & 3.4 & 240 \\
\hline $\mathrm{P}$ & 1.5 & 4.0 & 7.1 & 8.0 & 60 \\
\hline Fat & 38 & 43 & 20 & 273 & - \\
\hline C18:1 & 6.4 & 3.51 & 3.42 & 51.1 & - \\
\hline C18:2 & 12.34 & 10.40 & 8.43 & 50.0 & - \\
\hline C18:3 & 0.46 & 0.76 & 1.14 & 187.0 & - \\
\hline \multicolumn{6}{|c|}{${ }^{1}$ Energy concentrate on DM basis: $20 \%$ wheat, $20.0 \%$ corn, $20 \%$ barley, $15 \%$ wheat bran, $1 \%$ soya oil, $3 \%$ sugar } \\
\hline \multicolumn{6}{|c|}{$\begin{array}{l}{ }^{2} \text { Product contained } 30 \% \text { of wheat and } 70 \% \text { of Tradi-LIN extruded linseeds (Valorex, Combourtillé, France). } \\
{ }^{3} 6 \% \mathrm{P}, 24 \% \mathrm{Ca} \text {, and } 4 \% \mathrm{Mg} \text {. }\end{array}$} \\
\hline \multicolumn{6}{|c|}{$\begin{array}{l}{ }^{4} \mathrm{PDIE}=\text { protein digested in the small intestine supplied by rumen-undegraded dietary protein and by micro- } \\
\text { bial protein from rumen-fermented OM (Institut National de la Recherche Agronomique, 1989). }\end{array}$} \\
\hline
\end{tabular}

\section{MATERIALS AND METHODS}

\section{Animals}

In this study, 36 Prim'Holstein dairy cows were divided into 3 equal groups of 12 cows. Cows were allocated to groups based on parity (primiparous or multiparous), lactation stage $(104 \pm 18 \mathrm{~d})$, milk yield $(34.9 \pm 5.1 \mathrm{~kg} / \mathrm{d})$, milk fat content $(3.16 \pm 0.66 \%)$, milk protein content $(3.13 \pm 0.18 \%)$, milk fat globule size $(3.9 \pm 0.3 \mu \mathrm{m})$, liveweight $(627 \pm 65 \mathrm{~kg})$, total DMI $(22.0 \pm 2.7 \mathrm{~kg} / \mathrm{d})$, and BCS $(2.2 \pm 0.3)$.

\section{Treatments}

Three diet treatments were applied. The control treatment consisted of corn silage $(70 \%)$ plus cerealbased energy concentrate ( $12 \%$ of the ration). Protein input was delivered by soybean meal $48(16.5 \%$ of the ration). The first linseed treatment (LIN1) consisted of corn silage $(70 \%)$, cereal-based energy concentrate (9.5\%), and extruded linseed (2.1\% of the ration) delivered as Valomega 160 (Valorex, Combourtillé, France), introduced as a replacer for a portion of the soybean meal and energy concentrate. This mixed ration provided each dairy cow with $120 \mathrm{~g} / \mathrm{d}$ of ALA. The second linseed treatment (LIN2) consisted of corn silage $(70 \%)$, cereal-based energy concentrate $(6.8 \%)$, and extruded linseed (4.3\% of the ration) delivered as Valomega 160, introduced as a replacer for a portion of the soybean meal and energy concentrate. This mixed ration provided each dairy cow with $240 \mathrm{~g} / \mathrm{d}$ of ALA.
Feed composition is given in Table 1. Valomega 160 is made up of $30 \%$ wheat meal and $70 \%$ extruded TradiLin grain (Valorex, Combourtillé, France). TradiLin uses a patented process characterized by a preliminary maturing step of specific duration (10-30 min) and temperature $\left(<100^{\circ} \mathrm{C}\right)$, level of steam incorporation, and the mounting of the extruders (patent no. EP $1021960 \mathrm{~B} 1)$.

All rations had the same forage:concentrate ratio and were isoenergetic (1.67 Mcal $/ \mathrm{kg}$ of DM) and isonitrogenous [94 g of PDIE (metabolizable protein supply) $/ \mathrm{kg}$ of DM; Institut National de la Recherche Agronomique, 1989; Table 2]. Corn silage was completed with soybean meal 48 in all treatments to balance nitrogen input and with minerals. The animals were fed ad libitum and had no access to straw. Feeds were weighed and mechanically distributed twice daily, at 0800 and $1700 \mathrm{~h}$.

\section{Experimental Design}

The study was conducted over a continuous 12-wk period, starting with a 2-wk diet adaptation period followed by a 7-wk full diet period and a 3-wk posttrial period, during which all groups returned progressively to the control diet before being turned out to pasture.

\section{Measurements and Sampling Scheme}

Feeds and Orts. Voluntary DMI was recorded daily for each cow throughout the experiment via individual electronic gating. The DM content of corn silage was 
Table 2. Composition of experimental diets ${ }^{1}$

\begin{tabular}{|c|c|c|c|}
\hline Item & Control & LIN1 & LIN2 \\
\hline \multicolumn{4}{|l|}{ Ingredient, $\%$} \\
\hline Corn silage & 70 & 70 & 70 \\
\hline Energy concentrate & 12 & 9.5 & 6.8 \\
\hline Soybean meal & 16.5 & 16 & 15.5 \\
\hline Valomega $160^{2}$ & 0 & 3 & 6.2 \\
\hline Minerals & 1.5 & 1.5 & 1.5 \\
\hline \multicolumn{4}{|c|}{ Chemical composition, $\mathrm{g} / \mathrm{kg}$ of DM unless noted } \\
\hline $\mathrm{DM}, \%$ & 40.6 & 40.6 & 40.6 \\
\hline $\mathrm{OM}$ & 941 & 941 & 942 \\
\hline $\mathrm{CP}$ & 146 & 147 & 148 \\
\hline $\mathrm{NDF}$ & 329 & 332 & 335 \\
\hline $\mathrm{ADF}$ & 164 & 166 & 168 \\
\hline Starch & 278 & 270 & 261 \\
\hline Fat & 35.1 & 42.1 & 49.6 \\
\hline MUFA $^{3}$ & 5.5 & 6.9 & 8.4 \\
\hline PUFA $^{4}$ & 11.9 & 18.7 & 25.9 \\
\hline$\alpha$-Linolenic acid & 0.6 & 6.2 & 12.1 \\
\hline \multicolumn{4}{|c|}{ Nutritional value, $\mathrm{g} / \mathrm{kg}$ of DM unless noted } \\
\hline $\mathrm{NE}_{\mathrm{L}}, \mathrm{Mcal} / \mathrm{kg}$ of DM & 1.65 & 1.67 & 1.70 \\
\hline PDIE $^{5}$ & 93.4 & 94.3 & 95.2 \\
\hline $\mathrm{PDIN}^{6}$ & 96.9 & 98.2 & 99.7 \\
\hline
\end{tabular}

${ }^{1}$ Control $=$ corn silage $(70 \%)$ plus cereal-based energy concentrate $(12 \%$ of the ration) and soybean meal $(16.5 \%$ of the ration); LIN1 = corn silage $(70 \%)$, cereal-based energy concentrate $(9.5 \%)$, soybean meal $(16 \%$ of the ration), and extruded linseed (2.1\% of the ration); provided each dairy cow with $120 \mathrm{~g} / \mathrm{d}$ of $\alpha$-linolenic acid; LIN2 $=$ corn silage $(70 \%)$, cereal-based energy concentrate $(6.8 \%)$, soybean meal $(15.5 \%$ of the ration), and extruded linseed (4.3\% of the ration); provided each dairy cow with $240 \mathrm{~g} / \mathrm{d}$ of $\alpha$-linolenic acid.

${ }^{2}$ Valorex (Combourtillé, France).

${ }^{3} \mathrm{MUFA}=$ monounsaturated fatty acid.

${ }^{4} \mathrm{PUFA}=$ polyunsaturated fatty acid.

${ }^{5} \mathrm{PDIE}=$ protein digested in the small intestine supplied by rumen-undegraded dietary protein and by microbial protein from rumen-fermented OM (Institut National de la Recherche Agronomique, 1989).

${ }^{6} \mathrm{PDIN}=$ protein digested in the small intestine supplied by rumen-undegraded dietary protein and by microbial protein from rumen-degraded OM (Institut National de la Recherche Agronomique, 1989).

determined $\left(80^{\circ} \mathrm{C} ; 48 \mathrm{~h}\right)$ every $3 \mathrm{~d}$ to adjust the proportion of corn silage in the diets. Orts were collected and weighed daily before the morning feeding. To calculate DMI, orts were assumed to have a composition similar to the offered diet.

Animal Performance Parameters. The cows were milked daily at 0730 and $1630 \mathrm{~h}$ throughout the trial. Milk yield was measured at each milking. Milk protein content, milk fat content, and lipolysis were measured at each milking $3 \mathrm{~d} / \mathrm{wk}$ (Tuesday, Wednesday, and Thursday). Milk fat and protein contents were determined on an infrared dairy analyzer (MilkoScan, Foss Electric, Hillerød, Denmark) using the ISO 9622 method (ISO, 1999). The FFA acid content (lipolysis) of milk was measured by the copper soap method (Jellema, 1991). The animals were weighed at the same time every Wednesday.

Milk Fat Globule Size. Average milk fat globule diameter was measured on 3 replicates on each cow pretrial, at wk 8, and posttrial using a Coulter Multisizer II system (Coulter Electronics Ltd., Luton, UK) fitted with a vacuum suction control unit pierced with a $70 \mu \mathrm{m}$-diameter hole. This control unit measured the energy released by impacting particles as they passed through the hole. This gives a size class-stratified (0.177- $\mu \mathrm{m}$ class) count of fat globules flowing through the hole in a given time (20 s) and a size-stratified fat globule distribution profile. Milk samples were diluted in an electrolytic solution (Isoton II, Coulter Electronics Ltd.). Mean diameter $\mathrm{d}_{10}=\Sigma(\mathrm{Ni} \times \mathrm{di}) / \Sigma \mathrm{Ni}$ (where $\mathrm{Ni}=$ number of milk fat globules with diameter di) was used to compare treatments.

Milk Fatty Acid Composition and Yield. Milk FA composition was measured pretrial, at wk 8 , and posttrial (samples were weight-corrected from eveningmorning milkings). Fatty acid composition was determined on 1 replicate by lipid extraction from a $0.5-\mathrm{mL}$ sample of milk fat according to the method described in Bauchart and Duboisset (1983) using $0.5 \mathrm{~mL}$ of an ethanol/HCl [100:5 ( $\mathrm{vol} / \mathrm{vol})]$ solution followed by $5 \mathrm{~mL}$ of hexane. Milk FA were esterified with $1.0 \mathrm{~mL}$ of a methanol/NaOH [100:2, ( $\mathrm{vol} / \mathrm{vol})]$ solution followed by $1.0 \mathrm{~mL}$ of methanol boron trifluoride solution [(100:20 (vol/vol)] and $2 \mathrm{~mL}$ of hexane (methyl esters). These esters were extracted with $2 \mathrm{~mL}$ of $n$-hexane and injected into a Varian CP-3800 GC (Varian Inc., Palo 
Alto, CA) equipped with an electron ionization detector. Methyl esters were separated on an SP 2560 fused silica capillary column $(100 \mathrm{~m} \times 0.25 \mathrm{~mm}$ i.d.; Supelco Inc., Bellafonte, PA) starting at $90^{\circ} \mathrm{C}$ for $7 \mathrm{~min}$, then increasing $7^{\circ} \mathrm{C} / \mathrm{min}$ to reach $155^{\circ} \mathrm{C}$, then increasing $3^{\circ} \mathrm{C} / \mathrm{min}$ to reach $235^{\circ} \mathrm{C}$, then held at $235^{\circ} \mathrm{C}$ for $10 \mathrm{~min}$. Both injector and detector were at $230^{\circ} \mathrm{C}$. Carrier gas was helium. Yield of FA was calculated by multiplying milk FA percentage by milk fat yield and by a corrective factor of 0.86 (Lemosquet et al., 2009b).

\section{Butter Making}

Production Process. In wk 7 and 9, the milk from 4 milkings (2 morning and 2 evening) of 12 cows from each group was put into individual tanks. This milk was cooled to $4^{\circ} \mathrm{C}$ as quickly as possible by the tank cooling system. The milk was sent by truck to Elvir private research laboratory (Bongrain SA, Condé-surVire, France) to be skimmed and processed into butter. After prepasteurization $\left(78^{\circ} \mathrm{C}\right.$ for $\left.30 \mathrm{~s}\right)$, the milk was skimmed at $40^{\circ} \mathrm{C}$ in a centrifugal cream separator $(135$ L/h model, Elecrem, Châtillon, France). The cream collected was then standardized at $40 \%$ fat before being pasteurized $\left(88^{\circ} \mathrm{C}\right.$ for $\left.1 \mathrm{~min} 30 \mathrm{~s}\right)$. It was then snapcooled to $6^{\circ} \mathrm{C}$ using a plate heat exchanger. The cream was physically matured $\left(18^{\circ} \mathrm{C}\right.$ for $\left.3 \mathrm{~h}\right)$ before being recooled and held at $6^{\circ} \mathrm{C}$. Prior to churning, the cream had been acidified at $\mathrm{pH} 5.2$ using fermented dairy product [(acidity ranging from 1,600 to 1,800 Dornic degrees $\left.\left({ }^{\circ} \mathrm{D}\right)\right]$. The cream was then churned at $44 \mathrm{rpm}$ in a 120-L industrial churn (Simon Frères, Cherbourg, France) until the butter granulated. After separating the buttermilk, the butter was washed in $20 \mathrm{~kg}$ of water at $8^{\circ} \mathrm{C}$ before being preworked in the churn, first at low speed for 15 min then at high speed for 1 min. The butter was then worked in a butter-worker (MXT 63/3333 model, Simon Frères) before being packaged into individual butter sticks (at least 20/treatment per day).

Measurements. Cream churning time (time elapsed from time zero, when the churn was started, to time the butter granules formed), $\mathrm{pH}$, fat content (standard FT 120 Cream, IR Foss, calibrated to standard FIL 016 C; 1987) and DM (standard FIL 020-2 B, 2001) of the cream, buttermilk, and butter and butter iodine value (standard ISO 3961; ISO, 2009) were measured during the butter production process.

Butter FA composition was determined on 1 replicate using the same method as was used for the milk samples, but without the prior lipid extraction step. Color was assessed directly on the top surface of the butter sticks on 3 replicates using a Minolta CR-300 Chromameter (Minolta Camera Co. Ltd., Osaka, Japan) that was previously white-balanced and adjusted to the $\mathrm{L}^{*} \mathrm{a} * \mathrm{~b}$ color space (lightness, green index, yellow index).

Penetration resistance was measured on butters that had been stored 2 wk at $4^{\circ} \mathrm{C}$. Resistance was measured on butter immediately out of the cooler and on butter that had been stored at $13^{\circ} \mathrm{C}$ overnight $(3$ repetitions per type of butter). Penetration resistance measurements were performed on an Instron model 4501 universal testing machine (Instron Ltd., High Wycombe, UK) running IX software (Instron) and fitted with a $1-\mathrm{kN}$ load and a $90^{\circ}$ cone. Measurements were performed in triplicate in an air-conditioned room that was temperature-controlled at a constant $18^{\circ} \mathrm{C}$. The $90^{\circ}$ cone penetrated the sample at a constant $15 \mathrm{~mm} / \mathrm{min}$ rate to a depth of $18 \mathrm{~mm}$. The rheological variables measured were represented by slope and force (in N) at 5-, 10-, and 18- $\mathrm{mm}$ penetration depths.

Sensory analysis was conducted at the ENILIA National School of Milk and Agrifoods Industries (ENILIA, Surgères, France) 3 wk after the butters had been produced, at a tasting temperature of $14 \pm 1^{\circ} \mathrm{C}$ per ISO 22935-2 (ISO, 2009) guidelines. The jury was a trained panel of 8 tasters formed per ISO 22935-1 (ISO, 2009) standard guidelines (16 training sessions of $1 \mathrm{~h}$ 30 min for jury before the trial and after; 40 trainings/ yr). Data were collected and analyzed with FIZZ software (Biosystemes, Couternon, France). At each tasting session, members of the tasting jury were asked to score spreadability at $4^{\circ} \mathrm{C}$, color, smell (overall intensity and the aroma tones double cream, milk, cut grass, hazelnut, hay, and rancid), flavor (overall intensity, acid taste, and the aroma tones cream, milk, cooked milk, hazelnut, cut grass, rancid, metallic, and persistence of the flavor), firmness, and melt-in-the-mouth texture. Scores were given on a 0-to-10 scale, with higher scores given to higher intensities.

\section{Measurements and Sampling System for Blood Parameters}

On the Friday of wk 8, before the morning meal, 15 -mL blood samples were withdrawn from the tail into two 7.5-mL heparin tubes to assay acetate, glucose, urea, NEFA, BHBA, and total glycerol for each cow of the trial. The assays for glucose, urea, NEFA, total glycerol, and BHBA acid made on 2 replicates are reported in Delamaire and Guinard-Flament (2006) and Lemosquet et al. (2009a).

\section{Statistical Analysis}

Statistical analysis was carried out using the MIXED procedure of SAS (2005). Milk performances and intakes were determined using average data for the last 
Table 3. Effect of extruded linseeds on DM, energy, and protein intake of dairy cows

\begin{tabular}{|c|c|c|c|c|c|c|}
\hline \multirow[b]{2}{*}{ Variable } & \multicolumn{3}{|c|}{ Treatment $^{1}$} & \multirow[b]{2}{*}{$\mathrm{RMSE}^{2}$} & \multicolumn{2}{|c|}{ Contrast $^{3}$} \\
\hline & Control & LIN1 & LIN2 & & $\mathrm{L}$ & $\mathrm{Q}$ \\
\hline \multicolumn{7}{|c|}{ Ingestion, $\mathrm{kg}$ of $\mathrm{DM} / \mathrm{d}$ unless noted } \\
\hline Total & 22.6 & 22.1 & 22.2 & 1.56 & 0.532 & 0.617 \\
\hline As forage & 15.4 & 15.1 & 15.2 & 1.12 & 0.750 & 0.730 \\
\hline As concentrate & 7.2 & 7.0 & 7.0 & 0.45 & 0.159 & 0.416 \\
\hline \multicolumn{7}{|c|}{ Supply, g/d unless noted } \\
\hline $\mathrm{NE}_{\mathrm{L}}, \mathrm{Mcal} / \mathrm{d}$ & 37.6 & 37.1 & 37.1 & 2.74 & 0.678 & 0.728 \\
\hline $\mathrm{PDIE}^{4}$ & 2,187 & 2,138 & 2,136 & 157 & 0.428 & 0.685 \\
\hline $\mathrm{PDIN}^{5}$ & 2,308 & 2,259 & 2,268 & 163 & 0.563 & 0.643 \\
\hline $\mathrm{CP}$ & 3,466 & 3,378 & 3,372 & 246 & 0.371 & 0.654 \\
\hline$\alpha$-Linolenic acid & 12.6 & 136.8 & 268.5 & 12.98 & $<0.001$ & 0.450 \\
\hline
\end{tabular}

${ }^{1}$ Control $=$ corn silage $(70 \%)$ plus cereal-based energy concentrate $(12 \%$ of the ration) and soybean meal $(16.5 \%$ of the ration); LIN1 = corn silage $(70 \%)$, cereal-based energy concentrate $(9.5 \%)$, soybean meal $(16 \%$ of the ration), and extruded linseed (2.1\% of the ration); provided each dairy cow with $120 \mathrm{~g} / \mathrm{d}$ of $\alpha$-linolenic acid; LIN2 = corn silage $(70 \%)$, cereal-based energy concentrate $(6.8 \%)$, soybean meal $(15.5 \%$ of the ration), and extruded linseed (4.3\% of the ration); provided each dairy cow with $240 \mathrm{~g} / \mathrm{d}$ of $\alpha$-linolenic acid.

${ }^{2} \mathrm{RMSE}=$ root mean square error.

${ }^{3} \mathrm{~L}=$ contrast testing linear effect between control, LIN1, and LIN2; Q = contrast testing quadratic effect between control, LIN1, and LIN2.

${ }^{4} \mathrm{PDIE}=$ protein digested in the small intestine supplied by rumen-undegraded dietary protein and by microbial protein from rumen-fermented OM (Institut National de la Recherche Agronomique, 1989).

${ }^{5} \mathrm{PDIN}=$ protein digested in the small intestine supplied by rumen-undegraded dietary protein and by microbial protein from rumen-degraded OM (Institut National de la Recherche Agronomique, 1989).

3 wk of the experiment. Milk FA were determined only in wk 8. Variance-covariance analysis was run on the milk performance, intake, and milk FA composition parameters and on the individually measured milk fat and milk protein contents. The covariables included were cow performances or milk FA composition measured during the reference period. The statistical model used is as follows:

$$
Y_{i}=\mu+r_{i}+\operatorname{cov} Y_{i}+e_{i},
$$

where $Y_{i}$ is the variable, $\mu$ is the mean, $r_{i}$ is the treatment effect (control, LIN1, LIN2; 2 df), cov $Y_{i}$ is the covariable described above, and $\mathrm{e}_{\mathrm{i}}$ is the residual error.

Variance analysis was run on the cream, butter-making, butter properties, rheology, and color parameters and on the results of the sensory analysis. The statistical model used is as follows:

$$
\mathrm{Y}_{\mathrm{ij}}=\mu+\mathrm{r}_{\mathrm{i}}+\mathrm{p}_{\mathrm{j}}+\mathrm{e}_{\mathrm{ij}} \text {, }
$$

where $Y_{i j}$ is the variable, $\mu$ is the mean, $r_{i}$ is the treatment effect $(2 \mathrm{df}), \mathrm{p}_{\mathrm{j}}$ is the period effect $(1 \mathrm{df})$, and $\mathrm{e}_{\mathrm{ij}}$ is the residual error. A period corresponds to a date of butter-making.

Differences among treatments were compared using 2 orthogonal contrasts (i.e., linear and quadratic) using the orthogonal polynomial method (Gill, 1978). The results were expressed as least squares means with standard errors of the mean. The significance threshold was set at $P \leq 0.05$, and the trend threshold was set at $P \leq 0.10$.

\section{RESULTS}

\section{Intake and Milk Production}

Providing increasing doses of linseed in the ration had no effect on forage intake $(15.3 \mathrm{~kg}$ of $\mathrm{DM} / \mathrm{d})$, concentrate intake $(7.0 \mathrm{~kg}$ of $\mathrm{DM} / \mathrm{d})$, energy supply, or PDI (digestible protein supply; Table 3). Quantity of ALA delivered in the ration increased linearly from $12.6 \mathrm{~g} / \mathrm{d}$ with the control treatment up to $268.5 \mathrm{~g} / \mathrm{d}$ with the LIN2 treatment.

Providing increasing doses of linseed linearly increased milk yield $(+2.8 \mathrm{~kg} / \mathrm{d}$ with LIN2; Table 4) but linearly decreased protein content, fat yield, fat content, and FCM. There was no effect on protein production or cow liveweight. Providing increasing doses of extruded linseed linearly decreased milk fat globule diameter and linearly increased lipolysis. Energy balance linearly increased $(+1.80$ Mcal between control and LIN2), whereas PDI (digestible protein supply) balance decreased linearly $(-110 \mathrm{~g}$ between control and LIN2), although always stayed positive (Table 5).

\section{Plasma Composition}

Increasing doses of linseed in the ration had no effect on plasma glycerol, NEFA, glucose, acetate, and urea 
Table 4. Effect of extruded linseeds on milk production, fat and protein production, lipolysis, milk fat globule size, and body liveweight

\begin{tabular}{|c|c|c|c|c|c|c|}
\hline \multirow[b]{2}{*}{ Variable } & \multicolumn{3}{|c|}{ Treatment $^{1}$} & \multirow[b]{2}{*}{$\mathrm{RMSE}^{2}$} & \multicolumn{2}{|c|}{ Contrast $^{3}$} \\
\hline & Control & LIN1 & LIN2 & & $\mathrm{L}$ & $\mathrm{Q}$ \\
\hline Milk yield, $\mathrm{kg} / \mathrm{d}$ & 30.8 & 32.5 & 33.6 & 2.90 & 0.024 & 0.780 \\
\hline $\mathrm{FCM}, \mathrm{kg} / \mathrm{d}$ & 32.1 & 31.5 & 28.9 & 2.48 & 0.004 & 0.265 \\
\hline Fat content, $\%$ & 4.33 & 3.82 & 3.16 & 0.506 & $<0.001$ & 0.680 \\
\hline Protein content, $\%$ & 3.40 & 3.26 & 3.19 & 0.167 & 0.005 & 0.584 \\
\hline Fat yield, $\mathrm{g} / \mathrm{d}$ & 1,319 & 1,238 & 1,034 & 131.1 & $<0.001$ & 0.203 \\
\hline Protein yield, g/d & 1,039 & 1,055 & 1,069 & 76.3 & 0.360 & 0.981 \\
\hline Lipolysis, $\mathrm{mEq} / 100 \mathrm{~g}$ of fat & 0.37 & 0.61 & 0.70 & 0.269 & 0.005 & 0.445 \\
\hline Milk fat globule size, $\mu \mathrm{m}$ & 4.18 & 4.06 & 3.77 & 0.222 & $<0.001$ & 0.276 \\
\hline Liveweight, $\mathrm{kg}$ & 646 & 641 & 657 & 16.9 & 0.114 & 0.110 \\
\hline
\end{tabular}

${ }^{1}$ Control $=$ corn silage $(70 \%)$ plus cereal-based energy concentrate $(12 \%$ of the ration) and soybean meal (16.5\% of the ration); LIN1 = corn silage $(70 \%)$, cereal-based energy concentrate $(9.5 \%)$, soybean meal $(16 \%$ of the ration), and extruded linseed (2.1\% of the ration); provided each dairy cow with $120 \mathrm{~g} / \mathrm{d}$ of $\alpha$-linolenic acid; LIN2 = corn silage $(70 \%)$, cereal-based energy concentrate $(6.8 \%)$, soybean meal (15.5\% of the ration), and extruded linseed (4.3\% of the ration); provided each dairy cow with $240 \mathrm{~g} / \mathrm{d}$ of $\alpha$-linolenic acid.

${ }^{2} \mathrm{RMSE}=$ root mean square error.

${ }^{3} \mathrm{~L}=$ contrast testing linear effect between control, LIN1, and LIN2; $\mathrm{Q}=$ contrast testing quadratic effect between control, LIN1, and LIN2.

contents. The only plasma response identified was for BHBA content, which linearly decreased as linseed dose increased (Table 6).

\section{Milk Fatty Acid Profile and Yield}

Increasing linseed dose in the ration led to a linear decrease in saturated FA content, which induced an increase in monounsaturated and polyunsaturated FA (Table 7). Milk content of udder-synthesized FA (C6$\mathrm{C} 14)$ and palmitic acid (C16:0) decreased (up to -5.9 $\mathrm{g} / 100 \mathrm{~g}$ for C16:0 under the LIN2 treatment). Stearic acid content (C18:0) linearly increased with linseed dose. Refocusing on unsaturated FA, there was a linear increase in trans-6+7+8 C18:1, trans-9 C18:1, trans-12
C18:1, trans- $15+$ cis-11 C18:1, and cis-9+trans- 12 C18:1 FA, linoleic acid, and ALA. The ALA in fact increased 3-fold. The trans-10 C18:1 content varied little between control and LIN1 treatments, but increased sharply under the LIN2 treatment. Rumenic acid (cis-9,trans-11 C18:2) content remained unchanged. Excluding rumenic acid, all the other CLA increased with increased linseed dose, and the effect was more important at the highest dose. The $\mathrm{C} 16: 1 / \mathrm{C} 16: 0$ ratio, $\mathrm{C} 14: 1 / \mathrm{C} 14: 0$ ratio, and spreadability index (C18:1/C16:0) linearly increased, whereas C18:2/C18:3 ratio linearly decreased with linseed dose.

Increasing linseed dose led to a linear decrease in quantity of saturated FA (except C18:0), particularly odd- and even-numbered medium- and short-chain FA,

Table 5. Effect of extruded linseeds on energy and metabolic protein balances

\begin{tabular}{|c|c|c|c|c|c|c|}
\hline \multirow[b]{2}{*}{ Variable } & \multicolumn{3}{|c|}{ Treatment $^{1}$} & \multirow[b]{2}{*}{$\mathrm{RMSE}^{2}$} & \multicolumn{2}{|c|}{ Contrast $^{3}$} \\
\hline & Control & LIN1 & LIN2 & & $\mathrm{L}$ & $\mathrm{Q}$ \\
\hline $\mathrm{NE}_{\mathrm{L}}, \mathrm{Mcal} / \mathrm{d}$ & 2.52 & 2.36 & 4.32 & 2.70 & 0.110 & 0.289 \\
\hline $\mathrm{PDIE}^{4}, \mathrm{~g} / \mathrm{d}$ & 152 & 66 & 44 & 173 & 0.130 & 0.618 \\
\hline $\mathrm{PDIN}^{5}{ }^{5} \mathrm{~g} / \mathrm{d}$ & 272 & 187 & 176 & 178 & 0.192 & 0.575 \\
\hline
\end{tabular}

${ }^{1} \mathrm{Control}=$ corn silage $(70 \%)$ plus cereal-based energy concentrate $(12 \%$ of the ration) and soybean meal ( $16.5 \%$ of the ration); LIN1 = corn silage $(70 \%)$, cereal-based energy concentrate $(9.5 \%)$, soybean meal $(16 \%$ of the ration), and extruded linseed (2.1\% of the ration); provided each dairy cow with $120 \mathrm{~g} / \mathrm{d}$ of $\alpha$-linolenic acid; LIN2 = corn silage $(70 \%)$, cereal-based energy concentrate $(6.8 \%)$, soybean meal (15.5\% of the ration), and extruded linseed (4.3\% of the ration); provided each dairy cow with $240 \mathrm{~g} / \mathrm{d}$ of $\alpha$-linolenic acid.

${ }^{2} \mathrm{RMSE}=$ root mean square error.

${ }^{3} \mathrm{~L}=$ contrast testing linear effect between control, LIN1, and LIN2; $\mathrm{Q}=$ contrast testing quadratic effect between control, LIN1, and LIN2.

${ }^{4} \mathrm{PDIE}=$ protein digested in the small intestine supplied by rumen-undegraded dietary protein and by microbial protein from rumen-fermented OM (Institut National de la Recherche Agronomique, 1989).

${ }^{5} \mathrm{PDIN}=$ protein digested in the small intestine supplied by rumen-undegraded dietary protein and by microbial protein from rumen-degraded OM (Institut National de la Recherche Agronomique, 1989). 
Table 6. Effect of extruded linseeds on plasma composition during the whole experiment

\begin{tabular}{lccccccc}
\hline & \multicolumn{3}{c}{ Treatment $^{1}$} & & \multicolumn{2}{c}{ Contrast $^{3}$} \\
\cline { 2 - 4 } \cline { 6 - 7 } Variable & Control & LIN1 & LIN2 & & RMSE $^{2}$ & L & Q \\
\hline Total glycerol, mg/L & 66.5 & 66.8 & 72.4 & 11.11 & 0.198 & 0.946 \\
Acetate, $\mathrm{m} M / \mathrm{L}$ & 0.26 & 0.28 & 0.21 & 0.075 & 0.150 & 0.128 \\
BHBA, $\mathrm{m} M / \mathrm{L}$ & 0.48 & 0.43 & 0.36 & 0.108 & 0.009 & 0.731 \\
NEFA, $\mu M / \mathrm{L}$ & 97 & 97 & 102 & 29.4 & 0.673 & 0.807 \\
Glucose, $\mathrm{mg} / \mathrm{dL}$ & 77.1 & 77.6 & 78.6 & 4.51 & 0.446 & 0.885 \\
Urea, $\mathrm{mg} / \mathrm{dL}$ & 34.3 & 33.0 & 34.6 & 5.07 & 0.877 & 0.456 \\
\hline
\end{tabular}

${ }^{1}$ Control $=$ corn silage $(70 \%)$ plus cereal-based energy concentrate $(12 \%$ of the ration) and soybean meal ( $16.5 \%$ of the ration); LIN1 = corn silage $(70 \%)$, cereal-based energy concentrate $(9.5 \%)$, soybean meal $(16 \%$ of the ration), and extruded linseed (2.1\% of the ration); provided each dairy cow with $120 \mathrm{~g} / \mathrm{d}$ of $\alpha$-linolenic acid; LIN2 = corn silage $(70 \%)$, cereal-based energy concentrate $(6.8 \%)$, soybean meal $(15.5 \%$ of the ration), and extruded linseed (4.3\% of the ration); provided each dairy cow with $240 \mathrm{~g} / \mathrm{d}$ of $\alpha$-linolenic acid.

${ }^{2} \mathrm{RMSE}=$ root mean square error.

${ }^{3} \mathrm{~L}=$ contrast testing linear effect between control, LIN1, and LIN2; $\mathrm{Q}=$ contrast testing quadratic effect between control, LIN1, and LIN2.

C14:0 and C16:0 (Table 8). Increasing linseed dose had no significant effect on the quantity of monounsaturated FA. Only trans-10 C18:1 yield linearly increased. Increasing linseed dose led to an increase in the quantity of total polyunsaturated FA, particularly C18:3. In contrast, quantity of C18:2 decreased, whereas quantity of cis-9,trans-11 CLA increased only with LIN1 treatment.

\section{Physical Properties of Cream and Butter}

Increasing linseed dose in the ration led to a decrease in fat globule size in the cream processed into butter (Table 9). This effect was evident between the intermediate and high linseed doses. Cream fat contents were similar because of the standardization step. The $\mathrm{pH}$ followed the same pattern after the acidification step, which was also monitored. There was no treatment effect on churning time, even if the reduction in churning time from $54.5 \mathrm{~min}$ to either 41.5 or $45.0 \mathrm{~min}$ can be of great importance to manufacturers. Fat losses in buttermilk and butter moisture linearly increased. Increasing linseed doses led to a decrease in the fat content of the butters produced, but the effect was greater under the LIN2 treatment. The iodine value of the butters produced linearly increased.

At the 2 rheology test temperatures $\left(4^{\circ} \mathrm{C}\right.$ and $\left.13^{\circ} \mathrm{C}\right)$, butter firmness measured when burying the probe to $5 \mathrm{~mm}$ or $18 \mathrm{~mm}$ (maximum) linearly decreased with increasing linseed dose. Both butter firmness measured when burying the probe to $10 \mathrm{~mm}$ and slope were relatively unchanged between control butter and LIN1 butter, but decreased in LIN2 butter (Table 10).

\section{Butter Color and Sensory Properties}

Globally, there were no marked treatment effects on the color, smell, or flavor of the butters produced. The butters showed few specific sensory properties. Increasing linseed dose in the ration led to a slight linear decrease in butter brightness and yellow index (Table 11). Increasing doses of linseed led to a curvilinear increase in spreadability, and the effect was most significant at the highest linseed dose. It also linearly increased melt in the mouth and linearly decreased firmness (Table 12). However, providing increasing doses of linseed had no effect on aroma intensity or on individual aroma components. The only effect recorded was for rancid aroma, which tended to increase under the LIN1 and LIN2 treatments $(0.02 ; P=0.067)$, but the score stayed very low.

\section{DISCUSSION}

Replacing soybean meal and energy concentrate content of the ration with extruded linseed had no effect on feed intakes in dairy cows. The energy and protein inputs were therefore similar among control, LIN1, and LIN2 treatments, and energy balance and protein balance were always positive. Therefore, the observed effects on the zootechnical parameters and FA profile of the milks are directly attributable to the type of lipid source and the dose delivered.

\section{Linseed Supplementation Reduced Milk Fat Content}

Providing increasing doses of extruded linseed in the ration led to a weak increase in milk production, decreased protein content, and strongly decreased milk fat content. Milk fat content was $0.51 \%$ under LIN1 and almost $1.2 \%$ under the highest LIN2 dose (i.e., more than a $300 \mathrm{~g} / \mathrm{d}$ decrease in FA synthesized). With a mixture of linseed grains and linseed oil, Brunschwig et al. (1998) also highlighted higher milk production, lower milk fat content (lower than in our study), and 
a decrease in milk protein content. However, studies by Gonthier et al. (2005) on extruded linseed and by Chilliard and Ferlay (2004) on other forms of linseed found no effect on milk yield, fat, or protein contents.
This very clear effect of extruded linseed on milk fat content is almost similar to the effect of oil $[-0.94 \%$ with $4.4 \%$ linseed oil (Dhiman et al., 2000); $-0.49 \%$ with linseed oil salts (Chouinard et al., 1998)]. The

Table 7. Effect of extruded linseeds on milk fatty acid (FA) composition

\begin{tabular}{|c|c|c|c|c|c|c|}
\hline \multirow[b]{2}{*}{ Variable, \% } & \multicolumn{3}{|c|}{ Treatment $^{1}$} & \multirow[b]{2}{*}{$\mathrm{RMSE}^{2}$} & \multicolumn{2}{|c|}{ Contrast $^{3}$} \\
\hline & Control & LIN1 & LIN2 & & $\mathrm{L}$ & Q \\
\hline $\mathrm{C} 4: 0$ & 4.41 & 4.56 & 4.47 & 0.602 & 0.806 & 0.593 \\
\hline C6:0 & 2.84 & 2.73 & 2.44 & 0.396 & 0.024 & 0.525 \\
\hline $\mathrm{C} 7: 0$ & 0.04 & 0.03 & 0.02 & 0.013 & 0.003 & 0.970 \\
\hline C8:0 & 1.78 & 1.63 & 1.42 & 0.294 & 0.007 & 0.737 \\
\hline C9:0 & 0.04 & 0.03 & 0.02 & 0.012 & 0.003 & 0.204 \\
\hline C10:0 & 4.33 & 3.71 & 3.32 & 0.707 & 0.003 & 0.654 \\
\hline C10:1 & 0.37 & 0.33 & 0.30 & 0.080 & 0.037 & 0.814 \\
\hline C11:0 & 0.14 & 0.10 & 0.09 & 0.052 & 0.024 & 0.462 \\
\hline $\mathrm{C} 12: 0$ & 4.65 & 3.81 & 3.33 & 0.644 & $<0.001$ & 0.456 \\
\hline $\mathrm{C} 12: 1$ & 0.12 & 0.10 & 0.09 & 0.028 & 0.007 & 0.611 \\
\hline C13:0 & 0.15 & 0.12 & 0.09 & 0.041 & 0.002 & 0.930 \\
\hline C14:0 & 12.4 & 11.5 & 10.6 & 1.12 & 0.001 & 0.895 \\
\hline iso $\mathrm{C} 15: 0$ & 0.23 & 0.26 & 0.29 & 0.036 & 0.002 & 0.806 \\
\hline anteiso $\mathrm{C} 15: 0$ & 0.43 & 0.43 & 0.45 & 0.045 & 0.229 & 0.293 \\
\hline $\mathrm{C} 14: 1$ & 1.21 & 1.18 & 1.31 & 0.261 & 0.390 & 0.413 \\
\hline $\mathrm{C} 15: 0$ & 1.14 & 1.00 & 0.90 & 0.187 & 0.006 & 0.804 \\
\hline iso $\mathrm{C} 16: 0$ & 0.13 & 0.19 & 0.13 & 0.050 & 0.991 & 0.005 \\
\hline C16:0 & 32.7 & 29.4 & 26.8 & 2.22 & $<0.001$ & 0.693 \\
\hline iso $\mathrm{C} 17: 0$ & 0.41 & 0.49 & 0.53 & 0.058 & $<0.001$ & 0.420 \\
\hline $\mathrm{C} 16: 1$ & 1.65 & 1.54 & 1.69 & 0.376 & 0.803 & 0.351 \\
\hline $\mathrm{C} 17: 0$ & 0.43 & 0.42 & 0.41 & 0.051 & 0.390 & 0.876 \\
\hline $\mathrm{C} 18: 0$ & 7.80 & 8.91 & 9.00 & 1.39 & 0.048 & 0.323 \\
\hline trans $-6+7+8$ C18:1 & 0.25 & 0.31 & 0.43 & 0.071 & $<0.001$ & 0.209 \\
\hline trans-9 C18:1 & 0.22 & 0.25 & 0.33 & 0.047 & $<0.001$ & 0.105 \\
\hline trans-10 C18:1 & 0.60 & 0.92 & 2.17 & 0.607 & $<0.001$ & 0.043 \\
\hline trans-11 C18:1 & 1.23 & 1.40 & 1.32 & 0.376 & 0.594 & 0.396 \\
\hline cis-9 + trans-12 C18:1 & 14.9 & 18.1 & 19.6 & 2.13 & $<0.001$ & 0.286 \\
\hline trans $-15+$ cis-11 C18:1 & 0.57 & 0.69 & 0.92 & 0.090 & $<0.001$ & 0.085 \\
\hline cis-12 C18:1 & 0.25 & 0.25 & 0.20 & 0.044 & 0.026 & 0.075 \\
\hline cis-13 C18:1 & 0.04 & 0.05 & 0.05 & 0.023 & 0.411 & 0.673 \\
\hline cis-15 C18:1 & 0.07 & 0.11 & 0.23 & 0.053 & $<0.001$ & 0.052 \\
\hline $\mathrm{C} 18: 2$ & 1.73 & 1.87 & 1.91 & 0.246 & 0.094 & 0.613 \\
\hline Sum isomers C18:2 (without $\mathrm{CLA}^{4}$ ) & 0.47 & 0.76 & 1.32 & 0.225 & $<0.001$ & 0.099 \\
\hline $\mathrm{C} 20: 0$ & 0.070 & 0.073 & 0.131 & 0.069 & 0.047 & 0.277 \\
\hline C18:3 & 0.23 & 0.44 & 0.67 & 0.112 & $<0.001$ & 0.728 \\
\hline $\mathrm{C} 20: 1$ & 0.027 & 0.033 & 0.034 & 0.010 & 0.086 & 0.594 \\
\hline cis-9,trans-11 CLA & 0.52 & 0.62 & 0.60 & 0.153 & 0.210 & 0.321 \\
\hline Sum isomers CLA & 0.09 & 0.12 & 0.20 & 0.048 & $<0.001$ & 0.293 \\
\hline Sum FA >C20 & 0.41 & 0.50 & 0.58 & 0.169 & 0.022 & 0.902 \\
\hline Unknown FA & 0.88 & 1.02 & 1.49 & 0.182 & $<0.001$ & 0.022 \\
\hline Saturated FA & 74.1 & 69.3 & 64.7 & 2.60 & $<0.001$ & 0.951 \\
\hline Unsaturated FA & 24.1 & 28.4 & 31.9 & 2.44 & $<0.001$ & 0.703 \\
\hline Monounsaturated & 21.5 & 25.3 & 28.6 & 2.35 & $<0.001$ & 0.758 \\
\hline Polyunsaturated & 3.22 & 3.91 & 4.72 & 0.491 & $<0.001$ & 0.748 \\
\hline cis-9 C18:1/C18:0 & 1.95 & 2.08 & 2.20 & 0.344 & 0.098 & 0.947 \\
\hline $\mathrm{C} 14: 1 / \mathrm{C} 14: 0$ & 0.098 & 0.104 & 0.122 & 0.024 & 0.023 & 0.465 \\
\hline $\mathrm{C} 16: 1 / \mathrm{C} 16: 0$ & 0.052 & 0.052 & 0.063 & 0.012 & 0.037 & 0.247 \\
\hline cis-9 C18:1/C16:0 & 0.46 & 0.62 & 0.74 & 0.093 & $<0.001$ & 0.538 \\
\hline $\mathrm{C} 18: 2 / \mathrm{C} 18: 3$ & 8.41 & 4.44 & 2.88 & 1.749 & $<0.001$ & 0.061 \\
\hline
\end{tabular}

${ }^{1}$ Control $=$ corn silage $(70 \%)$ plus cereal-based energy concentrate $(12 \%$ of the ration) and soybean meal $(16.5 \%$ of the ration); LIN1 = corn silage $(70 \%)$, cereal-based energy concentrate $(9.5 \%)$, soybean meal $(16 \%$ of the ration), and extruded linseed (2.1\% of the ration); provided each dairy cow with $120 \mathrm{~g} / \mathrm{d}$ of $\alpha$-linolenic acid; LIN2 = corn silage $(70 \%)$, cereal-based energy concentrate $(6.8 \%)$, soybean meal (15.5\% of the ration), and extruded linseed (4.3\% of the ration); provided each dairy cow with $240 \mathrm{~g} / \mathrm{d}$ of $\alpha$-linolenic acid.

${ }^{2} \mathrm{RMSE}=$ root mean square error.

${ }^{3} \mathrm{~L}=$ contrast testing linear effect between control, LIN1, and LIN2; Q = contrast testing quadratic effect between control, LIN1, and LIN2.

${ }^{4} \mathrm{CLA}=$ conjugated linoleic acid. 
Table 8. Effect of extruded linseeds on milk fatty acid (FA) yields

\begin{tabular}{|c|c|c|c|c|c|c|}
\hline \multirow[b]{2}{*}{ Variable, g/d } & \multicolumn{3}{|c|}{ Treatment $^{1}$} & \multirow[b]{2}{*}{$\mathrm{RMSE}^{2}$} & \multicolumn{2}{|c|}{ Contrast $^{3}$} \\
\hline & Control & LIN1 & LIN2 & & $\mathrm{L}$ & $\mathrm{Q}$ \\
\hline Saturated FA & 843 & 748 & 578 & 94.4 & $<0.001$ & 0.288 \\
\hline $\mathrm{C} 5: 0$ to $\mathrm{C} 17: 0$ & 34.3 & 30.6 & 25.3 & 4.56 & $<0.001$ & 0.670 \\
\hline $\mathrm{C} 4: 0$ to $\mathrm{C} 12: 0$ & 205.9 & 178.1 & 134.9 & 33.26 & $<0.001$ & 0.544 \\
\hline C14:0 & 140.8 & 123.5 & 96.7 & 17.24 & $<0.001$ & 0.473 \\
\hline $\mathrm{C} 16: 0$ & 371.6 & 317.0 & 237.9 & 45.02 & $<0.001$ & 0.474 \\
\hline C18:0 & 87.7 & 96.6 & 80.6 & 18.39 & 0.385 & 0.076 \\
\hline Monounsaturated FA & 243 & 261 & 254 & 26.4 & 0.348 & 0.199 \\
\hline cis-9 C18:1 & 168.3 & 184.9 & 174.7 & 23.17 & 0.529 & 0.127 \\
\hline trans-10 C18:1 & 6.6 & 9.1 & 18.8 & 5.04 & $<0.001$ & 0.061 \\
\hline trans-11 C18:1 & 13.5 & 15.6 & 11.9 & 4.18 & 0.396 & 0.063 \\
\hline Polyunsaturated FA & 35.8 & 41.1 & 42.3 & 5.51 & 0.010 & 0.319 \\
\hline C18:3 & 2.7 & 4.6 & 5.9 & 1.02 & $<0.001$ & 0.406 \\
\hline C18:2 & 19.6 & 19.6 & 16.9 & 3.15 & 0.049 & 0.244 \\
\hline cis-9,trans-11 C18:2 & 5.6 & 6.8 & 5.4 & 1.56 & 0.840 & 0.038 \\
\hline
\end{tabular}

${ }^{1}$ Control $=$ corn silage $(70 \%)$ plus cereal-based energy concentrate $(12 \%$ of the ration) and soybean meal $(16.5 \%$ of the ration); LIN1 = corn silage $(70 \%)$, cereal-based energy concentrate $(9.5 \%)$, soybean meal $(16 \%$ of the ration), and extruded linseed (2.1\% of the ration); provided each dairy cow with $120 \mathrm{~g} / \mathrm{d}$ of $\alpha$-linolenic acid; LIN2 = corn silage $(70 \%)$, cereal-based energy concentrate $(6.8 \%)$, soybean meal (15.5\% of the ration), and extruded linseed (4.3\% of the ration); provided each dairy cow with $240 \mathrm{~g} / \mathrm{d}$ of $\alpha$-linolenic acid.

${ }^{2} \mathrm{RMSE}=$ root mean square error.

${ }^{3} \mathrm{~L}=$ contrast testing linear effect between control, LIN1, and LIN2; $\mathrm{Q}=$ contrast testing quadratic effect between control, LIN1, and LIN2.

extruded linseed may have induced changes in rumen fermentative activity, particularly at the highest linseed dose, resulting in changes in the hydrogenation activity of dietary FA and a greater production of trans-10 C18:1. The proportion and production of this
FA increased in the milk with increasing proportions of extruded linseed to the point where it represented $2.1 \%$ of total milk FA content. This FA, like cis-12,trans-10 C18:2, is known to inhibit the synthesis of short- and medium-chain FA in mammary epithelial cells (Bau-

Table 9. Effect of extruded linseeds on composition of cream, buttermilk, and butter

\begin{tabular}{|c|c|c|c|c|c|c|}
\hline \multirow[b]{2}{*}{ Variable } & \multicolumn{3}{|c|}{ Treatment $^{1}$} & \multirow[b]{2}{*}{$\mathrm{RMSE}^{2}$} & \multicolumn{2}{|c|}{ Contrast $^{3}$} \\
\hline & Control & LIN1 & LIN2 & & $\mathrm{L}$ & $\mathrm{Q}$ \\
\hline \multicolumn{7}{|l|}{ Cream properties } \\
\hline Fat globule size, $\mu \mathrm{m}$ & 4.18 & 4.07 & 3.49 & 0.150 & 0.017 & 0.174 \\
\hline Fat content, $\%$ & 40.5 & 40.5 & 40.2 & 0.68 & 0.662 & 0.854 \\
\hline $\mathrm{DM}, \mathrm{g} / \mathrm{kg}$ & 461.0 & 461.7 & 459.9 & 5.53 & 0.860 & 0.807 \\
\hline pH after acidification & 5.28 & 5.23 & 5.22 & 0.051 & 0.361 & 0.691 \\
\hline Churning time, $\min$ & 54.5 & 41.5 & 45.0 & 13.23 & 0.548 & 0.547 \\
\hline \multicolumn{7}{|l|}{ Buttermilk composition } \\
\hline Fat content, $\%$ & 5.3 & 6.0 & 17.6 & 2.32 & 0.030 & 0.114 \\
\hline $\mathrm{DM}, \mathrm{g} / \mathrm{kg}$ & 97.3 & 96.2 & 106.9 & 1.17 & 0.011 & 0.024 \\
\hline \multicolumn{7}{|l|}{ Butter composition } \\
\hline Fat content, $\%$ & 87.6 & 87.8 & 84.0 & 0.47 & 0.013 & 0.038 \\
\hline Nonfat content, \% & 1.04 & 0.95 & 1.02 & 0.043 & 0.682 & 0.149 \\
\hline Moisture, \% & 11.3 & 11.3 & 15.0 & 0.49 & 0.014 & 0.046 \\
\hline Iodine index & 28.4 & 31.9 & 38.2 & 0.85 & 0.005 & 0.199 \\
\hline
\end{tabular}

${ }^{1}$ Control $=$ corn silage $(70 \%)$ plus cereal-based energy concentrate $(12 \%$ of the ration) and soybean meal $(16.5 \%$ of the ration); LIN1 = corn silage $(70 \%)$, cereal-based energy concentrate $(9.5 \%)$, soybean meal $(16 \%$ of the ration), and extruded linseed (2.1\% of the ration); provided each dairy cow with $120 \mathrm{~g} / \mathrm{d}$ of $\alpha$-linolenic acid; LIN2 = corn silage (70\%), cereal-based energy concentrate (6.8\%), soybean meal (15.5\% of the ration), and extruded linseed (4.3\% of the ration); provided each dairy cow with $240 \mathrm{~g} / \mathrm{d}$ of $\alpha$-linolenic acid.

${ }^{2} \mathrm{RMSE}=$ root mean square error.

${ }^{3} \mathrm{~L}=$ contrast testing linear effect between control, LIN1, and LIN2; Q = contrast testing quadratic effect between control, LIN1, and LIN2. 
Table 10. Effect of extruded linseeds on texture of butters measured at $4^{\circ} \mathrm{C}$ and at $13^{\circ} \mathrm{C}$

\begin{tabular}{|c|c|c|c|c|c|c|}
\hline \multirow[b]{2}{*}{ Variable, $\mathrm{N}$ unless noted } & \multicolumn{3}{|c|}{ Treatment $^{1}$} & \multirow[b]{2}{*}{$\mathrm{RMSE}^{2}$} & \multicolumn{2}{|c|}{ Contrast $^{3}$} \\
\hline & Control & LIN1 & LIN2 & & $\mathrm{L}$ & $\mathrm{Q}$ \\
\hline \multicolumn{7}{|l|}{ Measures at $4^{\circ} \mathrm{C}$} \\
\hline Slope, $\mathrm{N} / \mathrm{cm}$ & 14.4 & 14.9 & 9.4 & 0.68 & 0.015 & 0.032 \\
\hline Firmness at $5 \mathrm{~mm}$ & 24.5 & 23.0 & 14.5 & 1.87 & 0.030 & 0.164 \\
\hline Firmness at $10 \mathrm{~mm}$ & 87.0 & 85.0 & 53.0 & 1.41 & 0.001 & 0.005 \\
\hline Maximum firmness & 163.0 & 157.0 & 97.0 & 8.64 & 0.013 & 0.067 \\
\hline \multicolumn{7}{|l|}{ Measures at $13^{\circ} \mathrm{C}$} \\
\hline Slope, N/cm & 4.93 & 4.43 & 2.22 & 0.223 & 0.005 & 0.045 \\
\hline Firmness at $5 \mathrm{~mm}$ & 10.0 & 8.5 & 4.0 & 0.707 & 0.010 & 0.134 \\
\hline Firmness at $10 \mathrm{~mm}$ & 32.5 & 29.0 & 14.0 & 1.47 & 0.004 & 0.043 \\
\hline Maximum firmness & 66.0 & 57.5 & 28.5 & 3.08 & 0.005 & 0.059 \\
\hline
\end{tabular}

${ }^{1}$ Control $=$ corn silage $(70 \%)$ plus cereal-based energy concentrate $(12 \%$ of the ration) and soybean meal (16.5\% of the ration); LIN1 = corn silage $(70 \%)$, cereal-based energy concentrate $(9.5 \%)$, soybean meal $(16 \%$ of the ration), and extruded linseed (2.1\% of the ration); provided each dairy cow with $120 \mathrm{~g} / \mathrm{d}$ of $\alpha$-linolenic acid; LIN2 = corn silage $(70 \%)$, cereal-based energy concentrate $(6.8 \%)$, soybean meal $(15.5 \%$ of the ration), and extruded linseed (4.3\% of the ration); provided each dairy cow with $240 \mathrm{~g} / \mathrm{d}$ of $\alpha$-linolenic acid.

${ }^{2} \mathrm{RMSE}=$ root mean square error.

${ }^{3} \mathrm{~L}=$ contrast testing linear effect between control, LIN1, and LIN2; $\mathrm{Q}=$ contrast testing quadratic effect between control, LIN1, and LIN2.

man and Griinari, 2001; Loor et al., 2005) and plays a role in the decrease in milk fat content. In this study, we were able to highlight a very clear negative correlation between milk short- and medium-chain FA content and milk trans-10 C18:1 content (Figure 1). It is now well established that cis-12,trans-10 C18:2 has very significant effects on fat synthesis. Because of technical constraints, the chromatography method used here did not isolate cis-12,trans-10 C18:2, but the increase in CLA other than rumenic acid following dietary intake of extruded linseed suggests that this acid may have also played a role in the sharp decrease in fat synthesis. Another possibility is that the decrease in short- and medium-chain FA may have been caused by the decrease in the precursors of these FA as BHBA.
The milk fat content of cows was very low during the pretrial period, possibly because of subacute acidosis caused by corn silage highly rich in starch (36\% of $\mathrm{DM})$. Even though the corn silage was changed at the start of the trial, enabling the control cows to return to a normal milk fat content a few days later, it is possible that the intake of extruded linseed against a background of subacute acidosis may have generated an accumulation of trans-10 C18:1 and a decrease in milk fat content (Loor et al., 2005; Chilliard et al., 2007). The composition of the basal diet is important in the establishment of milk fat depression, which has effects that become much more apparent when polyunsaturated FA are included in the diet (Bauman and Griinari, 2003). Changes in ruminal microbial populations, buffering

Table 11. Effect of extruded linseeds on butter color measured with a Minolta CR-300 Chromameter ${ }^{1}$

\begin{tabular}{|c|c|c|c|c|c|c|}
\hline \multirow[b]{2}{*}{ Variable $^{2}$} & \multicolumn{3}{|c|}{ Treatment $^{3}$} & \multirow[b]{2}{*}{$\mathrm{RMSE}^{4}$} & \multicolumn{2}{|c|}{ Contrast $^{5}$} \\
\hline & Control & LIN1 & LIN2 & & $\mathrm{L}$ & Q \\
\hline $\mathrm{L}^{*}$ & 93.4 & 92.9 & 93.0 & 0.42 & 0.437 & 0.486 \\
\hline$a^{*}$ & -2.68 & -2.64 & -2.63 & 0.020 & 0.115 & 0.430 \\
\hline $\mathrm{b}^{*}$ & 17.0 & 16.3 & 16.4 & 0.16 & 0.074 & 0.092 \\
\hline
\end{tabular}

${ }^{1}$ Minolta Camera Co. Ltd., Osaka, Japan.

${ }^{2} \mathrm{~L}^{*}=$ brightness from 0 (black) to 100 (white); $\mathrm{a}^{*}=$ scale of axis from red (positive value) to green (negative value); $b^{*}=$ scale of axis from yellow (positive value) to blue (negative value).

${ }^{3}$ Control $=$ corn silage $(70 \%)$ plus cereal-based energy concentrate $(12 \%$ of the ration) and soybean meal $(16.5 \%$ of the ration); LIN1 $=$ corn silage $(70 \%)$, cereal-based energy concentrate $(9.5 \%)$, soybean meal $(16 \%$ of the ration), and extruded linseed (2.1\% of the ration); provided each dairy cow with $120 \mathrm{~g} / \mathrm{d}$ of $\alpha$-linolenic acid; LIN2 = corn silage $(70 \%)$, cereal-based energy concentrate $(6.8 \%)$, soybean meal ( $15.5 \%$ of the ration), and extruded linseed (4.3\% of the ration); provided each dairy cow with $240 \mathrm{~g} / \mathrm{d}$ of $\alpha$-linolenic acid.

${ }^{4} \mathrm{RMSE}=$ root mean square error.

${ }^{5} \mathrm{~L}=$ contrast testing linear effect between control, LIN1, and LIN2; $\mathrm{Q}=$ contrast testing quadratic effect between control, LIN1, and LIN2. 


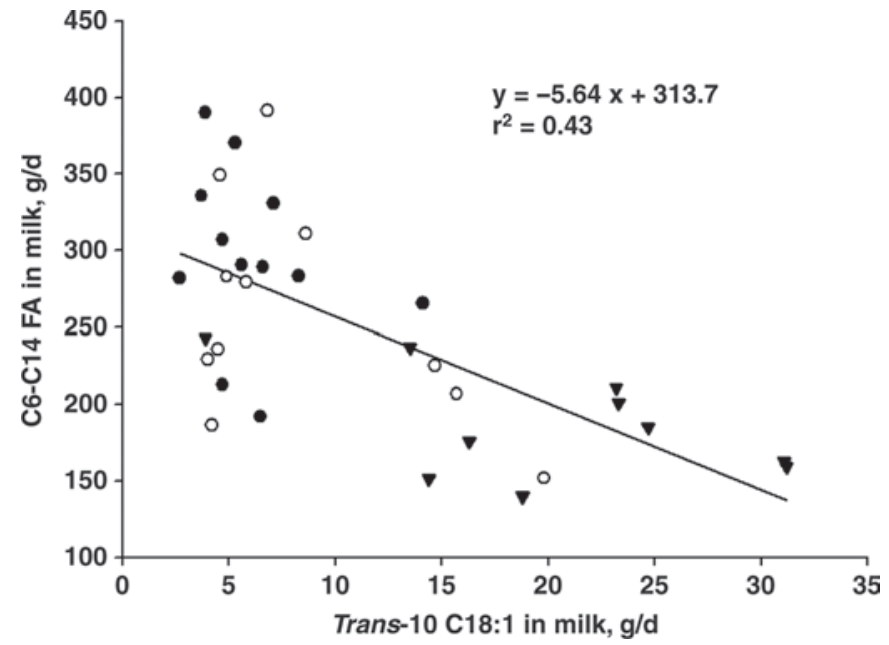

Figure 1. Relationship between quantity of trans-10 C18:1 in milk and quantity of $\mathrm{C} 6$ to $\mathrm{C} 14$ fatty acids synthesized in the mammary gland. - control; $\bigcirc=$ LIN1 (provided each dairy cow with $120 \mathrm{~g} / \mathrm{d}$ of $\alpha$-linolenic acid); $\boldsymbol{\nabla}=\mathrm{LIN} 2$ (provided each dairy cow with $240 \mathrm{~g} / \mathrm{d}$ of $\alpha$-linolenic acid). capacity, or increased passage rates with higher dietary starch intake may play a role in enhancing trans-C18:1 production in the rumen (Loor et al., 2005). All dairy cows returned to trans-10 C18:1 content below 0.7\% during the posttrial phase at pasture. Hence, it appears that the relatively dramatic effects of the high linseed dose on milk fat content and milk trans-10 C18:1 cannot be explained by any other factor than an effect intrinsic to linseed.

The decrease in fat synthesis and consequently in triglycerides under the LIN1 and even more clearly the LIN2 treatments could have led to glucose and glycerol sparing (Chilliard et al., 2000). Both of these substrates would therefore have been available to the mammary gland for lactose synthesis, which in turn may have been at the source of the increase in milk production with these 2 treatments, consequently enhancing the effect of lower FA synthesis on milk fat content. In parallel, animal liveweight increased under the LIN2 treatment (+10 kg compared with the control), which was directly

Table 12. Effect of extruded linseeds on sensory properties (scale of 0 to 10) of butter as determined by a jury

\begin{tabular}{|c|c|c|c|c|c|c|}
\hline \multirow[b]{2}{*}{ Variable } & \multicolumn{3}{|c|}{ Treatment $^{1}$} & \multirow[b]{2}{*}{$\mathrm{RMSE}^{2}$} & \multicolumn{2}{|c|}{ Contrast $^{3}$} \\
\hline & Control & LIN1 & LIN2 & & $\mathrm{L}$ & $\mathrm{Q}$ \\
\hline Spreadability & 5.46 & 4.56 & 7.53 & 1.503 & 0.001 & $<0.001$ \\
\hline Color & 1.33 & 1.30 & 1.33 & 0.571 & 0.980 & 0.856 \\
\hline \multicolumn{7}{|l|}{ Odor } \\
\hline Global intensity & 3.30 & 3.16 & 3.45 & 1.052 & 0.702 & 0.526 \\
\hline Heavy cream & 1.42 & 1.12 & 1.27 & 0.522 & 0.459 & 0.180 \\
\hline Milk & 2.57 & 2.31 & 2.55 & 1.051 & 0.938 & 0.461 \\
\hline Cut grass & 0.11 & 0.16 & 0.12 & 0.254 & 0.844 & 0.580 \\
\hline Hay & 0.06 & 0.07 & 0.06 & 0.032 & 0.564 & 0.448 \\
\hline Hazelnut & 0.24 & 0.25 & 0.20 & 0.398 & 0.802 & 0.799 \\
\hline Rancid & 0.05 & 0.07 & 0.07 & 0.021 & 0.067 & 0.389 \\
\hline \multicolumn{7}{|l|}{ Flavor } \\
\hline Global intensity & 3.43 & 3.29 & 3.12 & 1.010 & 0.417 & 0.949 \\
\hline Acid & 0.09 & 0.28 & 0.25 & 0.324 & 0.204 & 0.312 \\
\hline Cream & 1.62 & 1.68 & 1.80 & 0.683 & 0.492 & 0.899 \\
\hline Milk & 2.18 & 1.74 & 2.06 & 1.191 & 0.790 & 0.347 \\
\hline Hot milk & 0.44 & 0.75 & 0.68 & 0.487 & 0.186 & 0.238 \\
\hline Hazelnut & 0.23 & 0.30 & 0.26 & 0.359 & 0.819 & 0.604 \\
\hline Cut grass & 0.04 & 0.06 & 0.12 & 0.183 & 0.228 & 0.659 \\
\hline Rancid & 0.04 & 0.05 & 0.05 & 0.021 & 0.288 & 0.146 \\
\hline Metal & 0.07 & 0.04 & 0.20 & 0.378 & 0.352 & 0.451 \\
\hline Persistence & 3.02 & 3.47 & 2.82 & 0.907 & 0.572 & 0.060 \\
\hline \multicolumn{7}{|l|}{ Texture in mouth } \\
\hline Firm & 2.66 & 2.33 & 0.85 & 1.058 & $<0.001$ & 0.094 \\
\hline Melting & 4.91 & 5.42 & 6.60 & 1.552 & 0.006 & 0.500 \\
\hline Fat & 3.45 & 3.55 & 3.61 & 0.999 & 0.685 & 0.953 \\
\hline
\end{tabular}

${ }^{1}$ Control $=$ corn silage $(70 \%)$ plus cereal-based energy concentrate $(12 \%$ of the ration) and soybean meal ( $16.5 \%$ of the ration); LIN1 = corn silage $(70 \%)$, cereal-based energy concentrate $(9.5 \%)$, soybean meal $(16 \%$ of the ration), and extruded linseed (2.1\% of the ration); provided each dairy cow with $120 \mathrm{~g} / \mathrm{d}$ of $\alpha$-linolenic acid; LIN2 = corn silage (70\%), cereal-based energy concentrate (6.8\%), soybean meal (15.5\% of the ration), and extruded linseed (4.3\% of the ration); provided each dairy cow with $240 \mathrm{~g} / \mathrm{d}$ of $\alpha$-linolenic acid.

${ }^{2} \mathrm{RMSE}=$ root mean square error.

${ }^{3} \mathrm{~L}=$ contrast testing linear effect between control, LIN1, and LIN2; $\mathrm{Q}=$ contrast testing quadratic effect between control, LIN1, and LIN2. 
tied to the improved energy balance $(+1.7 \mathrm{Mcal} / \mathrm{d}$ compared with the control).

Besides the decrease in milk fat content, extruded linseed also tended to increase lipolysis. Chilliard et al. (1986) explained this effect as a consequence of enriching the ration in unprotected polyunsaturated FA-rich lipids.

\section{Linseed Supplementation Increased Milk and Butter C18:3 Content}

Adding linseed to the ration increased milk ALA content, thus confirming previous results (Gonthier et al., 2005; Schori et al., 2006); this effect was directly proportional to dietary linseed dose. These results are in accordance with Collomb et al. (2004) working with ground seed (1.0-1.4 kg/d, corresponding to $157 \mathrm{~g}$ and $224 \mathrm{~g}$ of ALA, respectively), and Flowers et al. (2008) working with increasing doses of linseed oil (170- 510 $\mathrm{g} / \mathrm{d})$. In our trial, the quantity of ALA secreted into milk represented $19.2 \%$ (control), 3.5\% (LIN1), and $2.2 \%$ (LIN2) of total ALA ingested, which confirms that ALA was exposed to important ruminal biohydrogenation when supplied in large quantities in the ration. This rate is close to the $2 \%$ rate calculated by Gonthier et al. (2005) and to the rates of 1.4, 1.9, and $0.5 \%$ calculated by Chilliard et al. (2009) for crude linseed, extruded linseed, and linseed oil, respectively, and the rate obtained with camelina seed or meal (1.7-2.6\%; Hurtaud and Peyraud, 2007), but less than the rate obtained with pasture grass (averaging 3.9\%; Hurtaud et al., 2008). This is probably the reason why introducing linseed led to an increase in most of the C18:1 and C18:2 isomers determined by chromatography (Chilliard et al., 2000, 2009). Finally, feeding extruded linseed enabled a strong decrease in the C18:2/C18:3 ratio, which decreased from 8.4 to 2.9 with the highest linseed dose.

However, it is important to emphasize that extruded linseed had no effect on milk rumenic acid content or on milk trans-11 C18:1 content. This result is probably because of ruminal digestion, which apparently essentially produced trans-10 C18:1 and not trans-11 C18:1. Indeed, blocked trans-11 C18:1 desaturation can be ruled out as an explanation for the lack of effect on milk rumenic acid content because linseed appears to have managed to slightly increase the desaturation index of the udder, as demonstrated by increased C14:1/ C14:0 and $\mathrm{C} 16: 1 / \mathrm{C} 16: 0$ ratios.

There are several potential reasons for the decrease in C16:0 yield or content with increasing linseed, including 1) long-chain FA are potent inhibitors of mammary FA synthesis, through a direct inhibitory effect on acetyl CoA carboxylase activity and 2) there was a

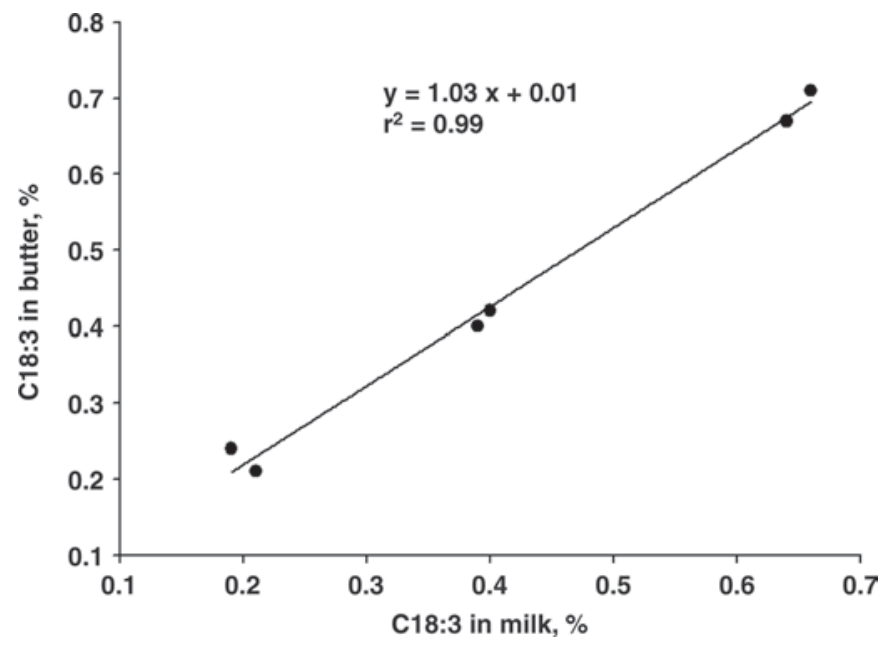

Figure 2. Relationship between milk and butter C18:3 content.

lower availability of acetate and BHBA (especially for LIN2) for mammary FA synthesis, possibly because of a lower acetate:propionate ratio in the rumen brought about by the increase in unsaturated fat (Chilliard et al., 2000).

All of the linseed effects on FA profile of milks were reproduced in the FA profiles of the butters; the 2 profile sets intercorrelated strongly. This is illustrated in Figures 2 and 3 with ALA and the C18:2/C18:3 ratio.

Globally, introducing increasing doses of extruded linseed into dairy cow feed ration improved the nutritional profile of the milks: less atherogenic palmitic acid, C18:2/C18:3 ratio reduced to below 5 as recommended by AFSSA (2003; the French National Food Safety Agency), and an increase in ALA. Furthermore, the improvements were greater at higher linseed doses. Feeding dairy cows corn silage-based rations, particularly with added linseed, makes it possible to produce milk and butter that is well suited to the nutritional needs of human consumers.

\section{Linseed Input Changed the Rheological and Sensory Properties of Butter, Particularly at the Highest Linseed Dose}

Introducing extruded linseed grains had marked effects on the production, composition, or properties of butters. All these effects were more important at the highest linseed dose treatment. The LIN1 treatment improved the nutritional value of butter without changing the production parameters or product performance properties. The LIN2 treatment led to 2 -fold higher fat losses in the buttermilk than the other treatments, and the moisture content of butters was higher. These results are likely related to the marked effect of the LIN2 


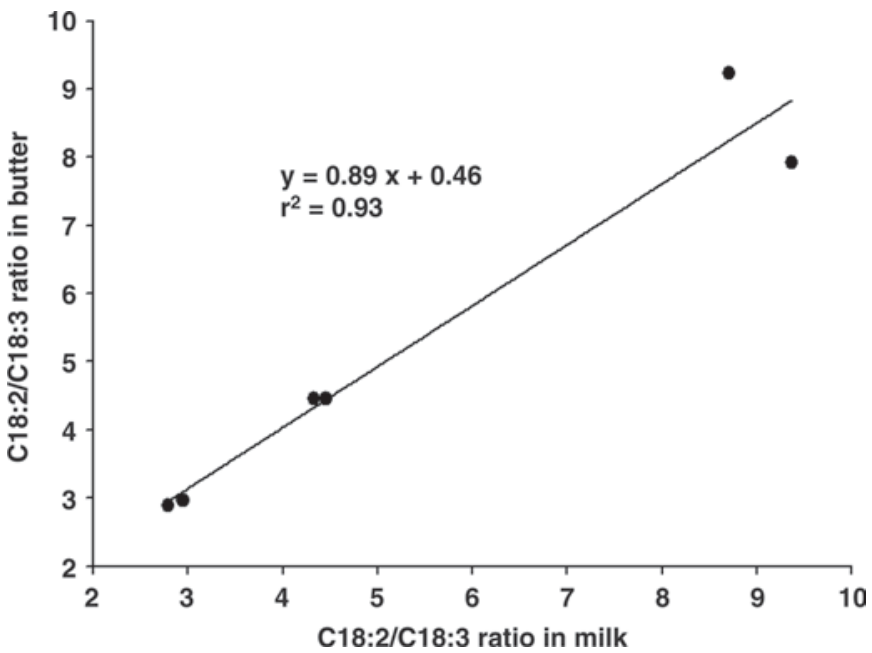
tios.

Figure 3. Relationship between milk and butter C18:2/C18:3 ra-

treatment on milk - and therefore cream-fat globule size: milk fat globule diameter was smaller $(-0.7 \mu \mathrm{m})$ than under the control treatment. The decrease in fat globule size with increasing linseed doses in the ration is consistent with Wiking et al. (2004), who linked this pattern to a decrease in milk fat content, and with Briard et al. (2003), who explained the pattern by an increase in the content of unsaturated FA, which are a major component of the fat globule membrane. The smaller fat globules may have been able to escape from the buttermilk instead of being integrated into the butter matrix. According to Goudédranche et al. (2000) and Michalski (2004), moisture of butters is higher when produced from creams with smaller fat globules, or creams rich in unsaturated FA, or both. It was suggested that the higher moisture content was linked to the hydrophilic membrane properties of the fat globules imprisoned in the fat-formed matrix, which retains water (Michalski, 2004).

Instrument-measured butter hardness was much lower under the LIN2 treatment and was well correlated to the firmness and melt-in-the-mouth characteristics determined by the taster jury performing sensory analysis, in accordance with previous reports (Wood et al., 1975; Badings et al., 1976; Rowney and Christian, 1996). These effects were particularly marked with the highest linseed dose. The milk FA composition of LIN2 cream affected butter texture by implementing the amount of fat that is in solid or liquid phase. Sometimes a strongly unsaturated FA composition is not desirable because it causes oiling off at higher temperatures and a loss of structure (Chen et al., 2004). Any important default occurred in our experiment because the rheological measures were made at $18^{\circ} \mathrm{C}$. The increase in unsaturated FA (particularly cis-9 C18:1) and the decrease in saturated FA (particularly $\mathrm{C} 4: 0$ and $\mathrm{C} 16: 0$ ) following the increased linseed dose in the ration led to a decrease in the quantity of fat crystallized at $4^{\circ} \mathrm{C}$ and $14^{\circ} \mathrm{C}$, thus explaining the differences in the results of rheological and sensory analysis.

The absence of taste and flavor defects in butters produced under the LIN1 and LIN2 treatments could appear surprising given the high butter content of unsaturated FA. This same finding has previously been reported for butters obtained from pasture-based diets: greater proportions of grass in the ration correlate to fewer taste defects (Couvreur et al., 2006). Chen et al. (2004) and Nelson and Martini (2009) highlighted this same absence of taste defects when dairy cows were fed rations with added unsaturated FA.

\section{CONCLUSIONS}

This trial confirmed that the change in dairy cow diet strongly affected milk FA profile. This in turn had repercussions on the nutritional value of the dairy end products, with linseed input leading to an increase in unsaturated FA and ALA and a decrease in palmitic acid. However, it is important to carefully analyze the lipid input conditions to avoid the massive production of trans FA by overly high doses or nonoptimal rumen conditions. Providing high doses of linseed can also have negative effects on end product processing, such as generating important material losses during the churning stage. Furthermore, the butter obtained can appear slightly oily at regular consumption temperatures. The aim is therefore to find the optimal input dose enabling the linseed input to balance out improved end product nutritional value, good workability, and positively perceived sensory qualities of the processed milk-based product, which in this case is butter. Based on our approach, we conclude that the LIN1 treatment offers a good compromise.

\section{ACKNOWLEDGMENTS}

The authors acknowledge the financial support of the agroindustrial group Valorex (Combourtillé, France). We thank A. Mottin, M. Fargetton, and their team (INRA-Agrocampus Ouest, UMR Production du lait, domaine de Méjussaume, Le Rheu, France) for their contributions to animal care and help with the raw milk separation process. We also thank A. Brasseur, N. Huchet, I. Jicquel, and M. Vérité (INRA-Agrocampus Ouest UMR Production du Lait, Saint-Gilles, France) for their technical assistance. The authors are indebted to D. Brodin and J. Durand for butter-making at the ELVIR private research laboratory (Bongrain SA, 
Condé-sur-Vire, France) and for their important advice. We also thank ATT (Clermont-Ferrand, France) for proofreading the manuscript.

\section{REFERENCES}

Agence Française de Sécurité Sanitaire des Aliments (AFSSA). 2003. Acides gras de la famille des oméga 3 et système cardiovasculaire: Intérêt nutritionnel et allégations. Paris, France.

ANC. 2001. Apports Nutritionnels Conseillés pour la Population Française. Tec et Doc, Paris, France.

Badings, H. T., S. Tamminga, and J. E. Schaap. 1976. Production of milk with a high content of polyunsaturated fatty acids. 2. Fatty acid composition of milk in relation to the quality of pasteurized milk, butter and cheese. Neth. Milk Dairy J. 30:118-131.

Bauchart, D., and F. Duboisset. 1983. Utilisation des colonnes capillaires de verre pour l'analyse des acides gras du lait. Cah. Techn. INRA 1:37-46.

Bauman, D. E., and J. M. Griinari. 2001. Regulation and nutritional manipulation of milk fat: Low-fat milk syndrome. Livest. Prod. Sci. 70:15-29.

Bauman, D. E., and J. M. Griinari. 2003. Nutritional regulation of milk fat synthesis. Annu. Rev. Nutr. 23:203-227.

Briard, V., N. Leconte, F. Michel, and M. C. Michalski. 2003. The fatty acid composition of small and large naturally occurring milk fat globules. Eur. J. Lipid Sci. Technol. 105:677-682

Brunschwig, P., P. Kernen, and P. Weill. 1998. Effets d'une supplémentation en acides gras polyinsaturés sur les performances de vaches laitières en milieu de lactation. Renc. Rech. Rum. $5: 262$.

Chen, S., G. Bobe, S. Zimmerman, E. G. Hammond, C. M. Luhman, T. D. Boylston, A. E. Freeman, and D. C. Beitz. 2004. Physical and sensory properties of dairy products from cows with various milk fatty acid compositions. J. Agric. Food Chem. 52:3422-3428.

Chilliard, Y., M. P. Chazal, and P. Cartier. 1986. Données récentes sur la lipolyse du lait de vache. Rev. ENIL 112:12-19.

Chilliard, Y., and A. Ferlay. 2004. Dietary lipids and forages interactions on cow and goat milk fatty acid composition and sensory properties. Reprod. Nutr. Dev. 44:467-492.

Chilliard, Y., A. Ferlay, R. M. Mansbridge, and M. Doreau. 2000 Ruminant milk fat plasticity: Nutritional control of saturated, polyunsaturated, trans and conjugated fatty acids. Ann. Zootech. 49:181-205.

Chilliard, Y., F. Glasser, F. Enjalbert, A. Ferlay, F. Bocquier, and P. Schmidely. 2007. Données récentes sur les effets de l'alimentation sur la composition en acides gras du lait de vache, de chèvre et de brebis. Renc. Rech. Rum. 14:321-328.

Chilliard, Y., C. Martin, J. Rouel, and M. Doreau. 2009. Milk fatty acids in dairy cows fed whole crude linseed, extruded linseed, or linseed oil, and their relationship with methane output. J. Dairy Sci. 92:5199-5211.

Chouinard, P. Y., V. Girard, and G. J. Brisson. 1998. Fatty acid profile and physical properties of milk fat from cows fed calcium salts of fatty acids with varying unsaturation. J. Dairy Sci. 81:471-481.

Collomb, M., H. Sollberger, U. Bütikofer, R. Sieber, W. Stoll, and W. Schaeren. 2004. Impact of a basal diet of hay and fodder beet supplemented with rapeseed, linseed and sunflowerseed on the fatty acid composition of milk fat. Int. Dairy J. 14:549-559.

Couvreur, S., C. Hurtaud, C. Lopez, L. Delaby, and J. L. Peyraud. 2006. The linear relationship between the proportion of fresh grass in the cow diet, milk fatty acid composition, and butter properties. J. Dairy Sci. 89:1956-1969.

Delamaire, E., and J. Guinard-Flament. 2006. Longer milking intervals alters mammary epithelial permeability and the udder's ability to extract nutrients. J. Dairy Sci. 89:2007-2016.

Dhiman, T. R., L. D. Satter, M. W. Pariza, M. P. Galli, K. Albright, and M. X. Tolosa. 2000. Conjugated linoleic acid (CLA) content of milk from cows offered diets rich in linoleic and linolenic acid. J. Dairy Sci. 83:1016-1027.
Flowers, G., S. A. Ibrahim, and A. A. AbuGhazaleh. 2008. Milk fatty acid composition of grazing dairy cows when supplemented with linseed oil. J. Dairy Sci. 91:722-730.

Gill, J. L. 1978. Completely randomized designs of analysis of variance. Pages 135-258 in Design and Analysis of Experiments in the Animal and Medical Sciences. Vol. 1. Iowa State University Press, Ames.

Gonthier, C., A. F. Mustafa, D. R. Ouellet, P. Y. Chouinard, R. Berthiaume, and H. V. Petit. 2005. Feeding micronized and extruded flaxseed to dairy cows: Effects on blood parameters and milk fatty acid composition. J. Dairy Sci. 88:748-756.

Goudédranche, H., J. Fauquant, and J. L. Maubois. 2000. Fractionation of globular milk fat by membrane microfiltration. Lait 80:93-98.

Harvatine, K. J., Y. R. Boisclair, and D. E. Bauman. 2009. Recent advances in the regulation of milk fat synthesis. Animal 3:4054 .

Hurtaud, C., E. Pérez-Ramìrez, L. Delaby, and R. Delagarde. 2008. Composition en acides gras du lait: Impact d'une restriction du temps d'accès au pâturage des vaches laitières en interaction avec la quantité de maïs à l'auge. Renc. Rech. Rum. 15:105-107.

Hurtaud, C., and J. L. Peyraud. 2007. Effects of feeding camelina (seeds or meal) on milk fatty acid composition and butter spreadability. J. Dairy Sci. 90:5134-5145.

Institut National de la Recherche Agronomique. 1989. Ruminant Nutrition: Recommended Allowances and Feed Tables. R. Jarrige, ed. John Libbey, London, UK.

ISO. 2008. ISO 2450/Standard 016: Cream. Determination of fat content. Gravimetric method. ISO, Geneva, Switzerland.

ISO. 2009. ISO 3961: Corps gras d'origines animale et végétale. Détermination de l'indice d'iode. ISO, Geneva, Switzerland.

ISO. 2001. ISO 8968-2/Standard 020-2: Milk. Determination of nitrogen content. ISO, Geneva, Switzerland.

ISO. 1999. ISO 9622: Whole milk. Determination of milkfat, protein and lactose content. Guidance on the operation of mid-infrared instruments. ISO, Geneva, Switzerland.

ISO. 2009. ISO 22935-1/IDF 099-1: Milk and milk products. Sensory analysis-Part 1: General guidance for the recruitment, selection, training and monitoring of assessors. ISO, Geneva, Switzerland.

ISO. 2009. ISO 22935-2/IDF 099-2: Milk and milk products. Sensory analysis-Part 2: Recommended methods for sensory evaluation. ISO, Geneva, Switzerland.

Jellema, A. 1991. Determination of free fatty acids in milk and milk products. Bulletin no. 265. International Dairy Federation, Brussels, Belgium.

Kelly, M. L., J. R. Berry, D. A. Dwyer, J. M. Griinari, P. Y. Chouinard, M. E. Van Amburgh, and D. E. Bauman. 1998. Dietary fatty acid sources affect conjugated linoleic acid concentrations in milk from lactating dairy cows. J. Nutr. 128:881-885.

Lemosquet, S., E. Delamaire, H. Lapierre, J. W. Blum, and J. L. Peyraud. 2009a. Effects of glucose, propionic acid, and nonessential amino acids on glucose metabolism and milk yield in Holstein dairy cows. J. Dairy Sci. 92:3244-3257.

Lemosquet, S., G. Raggio, G. E. Lobley, H. Rulquin, J. GuinardFlament, and H. Lapierre. 2009b. Whole-body glucose metabolism and mammary energetic nutrient metabolism in lactating dairy cows receiving digestive infusions of casein and propionic acid. J. Dairy Sci. 92:6068-6082.

Loor, J. J., A. Ferlay, A. Ollier, M. Doreau, and Y. Chilliard. 2005. Relationship among trans and conjugated fatty acids and bovine milk fat yield due to dietary concentrate and linseed oil. J. Dairy Sci. $88: 726-740$.

Michalski, M. C. 2004. Milkfat globules: Physico-chemical properties as a function of size. Bull. Int. Dairy Fed. 389:104-107.

Nelson, K. A. S., and S. Martini. 2009. Increasing omega fatty acid in cow's milk through diet manipulation: Effect on milk flavor. J. Dairy Sci. 92:1378-1386.

Nicolis, R. J. 1997. Dietary fat saturation effects on low-density lipoprotein concentration and metabolism in various animal models. Am. J. Clin. Nutr. 65:597-610.

Offer, N. W., M. Marsden, J. Dixon, B. K. Speake, and F. E. Thacker. 1999. Effect of dietary fat supplements on levels of n-3 poly- 
unsaturated fatty acids, trans acids and conjugated linoleic acid in bovine milk. Anim. Sci. 69:613-625.

Rowney, M., and M. Christian. 1996. Effect of cow diet and stage of lactation on the composition of milkfat for cheese manufacture. Aust. J. Dairy Technol. 51:118-122.

SAS Institute. 2005. User's Guide: Statistics. SAS Institute Inc., Cary, NC.

Schori, F., C. Fragnière, W. Schaeren, and W. Stoll. 2006. Graines de lin et de tournesol dans l'alimentation de la vache laitière. Rev. Suisse Agric. 38:25-30.

Valorex. 2001. Procédé de détoxification des graines de lin. Patent No. EP 1021960 B1.
Ward, A. T., K. M. Wittenberg, and R. Przybylski. 2002. Bovine milk fatty acid profiles produced by feeding diets containing solin, flax, and canola. J. Dairy Sci. 85:1191-1196.

Wiking, L., J. Stagsted, L. Björck, and J. H. Nielsen. 2004. Milk fat globule size is affected by fat production in dairy cows. Int. Dairy J. 14:909-913.

Williams, C. M. 2000. Dietary fatty acids and human health. Ann. Zootech. 49:165-180.

Wood, F. W., M. F. Murphy, and W. L. Dunkley. 1975. Influence of elevated polyunsaturated fatty acids on processing and physical properties of butter. J. Dairy Sci. 58:839-845. 